\title{
Imaging the Seascapes of the Mediterranean
}

BY DAVID AMBLÀS, MIQUEL CANALS, GALDERIC LASTRAS,

SERGE BERNÉ, AND BENOÎT LOUBRIEU

he Mediterranean Sea is a relative newcomer to Earth's landscape. Due to its complex tectonic history, this mid-latitude sea is composed of a cluster of basins.

Their seascape is in most cases dominated by geologically young structures, but also by sedimentary processes. Among the latter, sedimentary processes related to the dynamics of the largest rivers in the Mediterranean (Ebro, Rhône, Po, Danube, and Nile) stand out. This overview article illustrates the main sedimentary processes and their products contributing to shape the Mediterranean seascape within a source-tosink approach. To highlight this approach, this article mainly focuses on one of the EUROSTRATAFORM project study areas: the northwestern Mediterranean. 


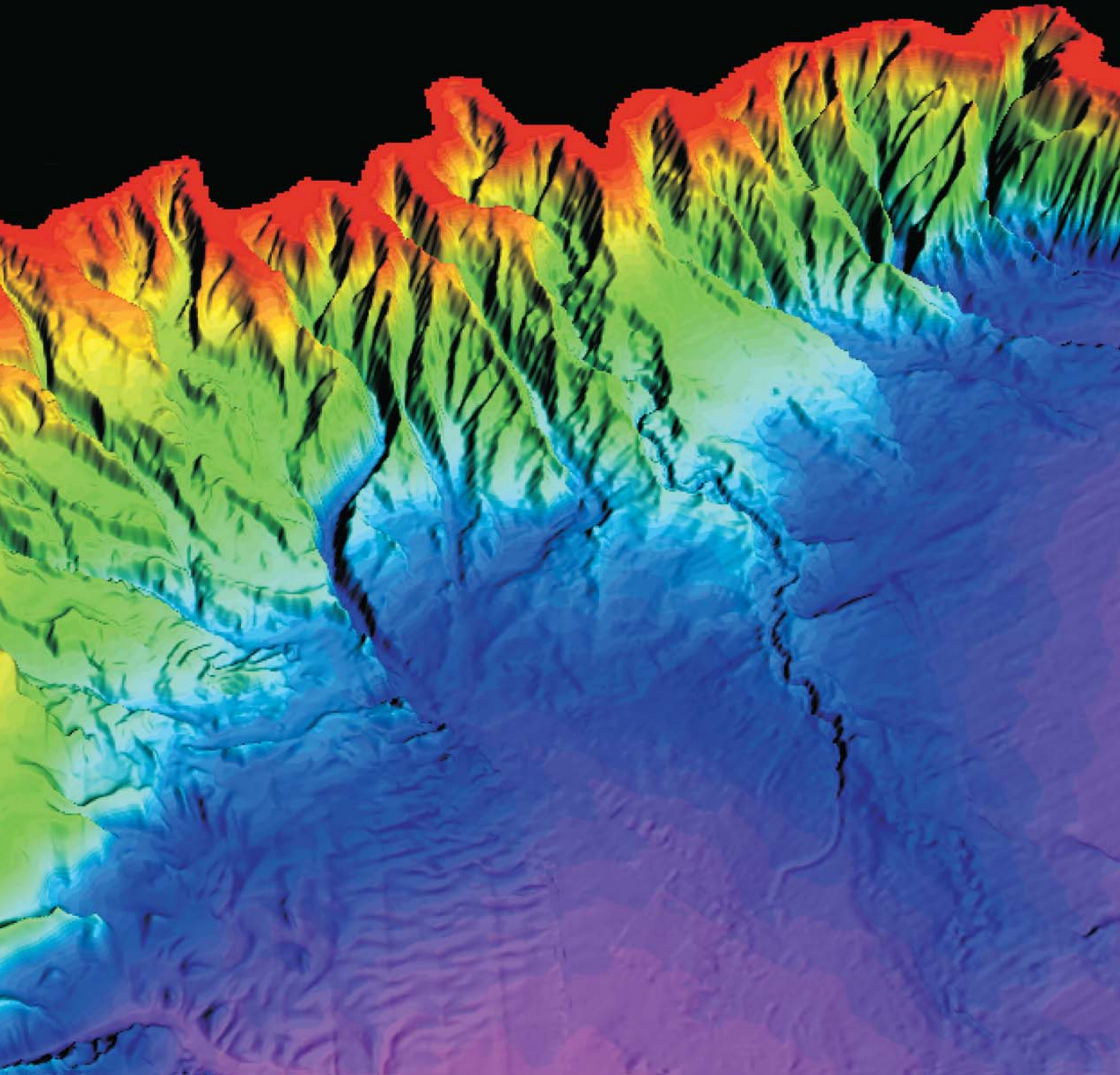




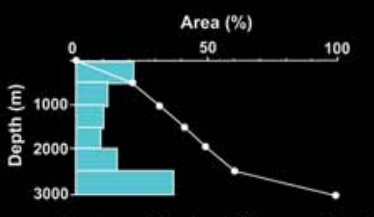

Western Basins (Alboran Sea (1) Catalano-Balearic Sea (2), Gulf of Lions (3) Ligurian Sea (4), Algerian-Balearic Basin (5))
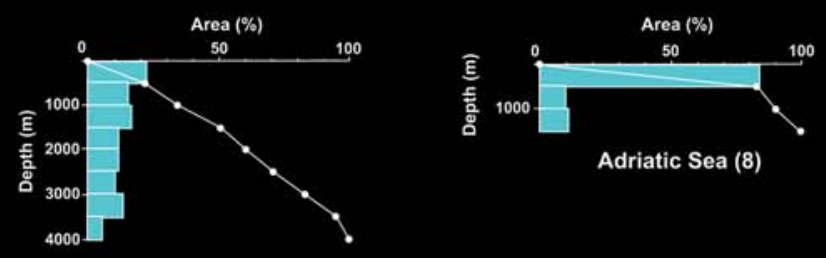

Thyrrhenian Basin (6)

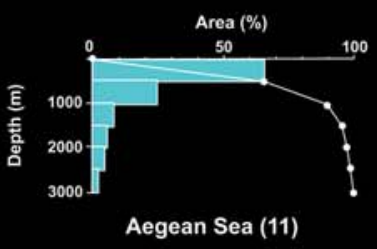

Aegean Sea (11)

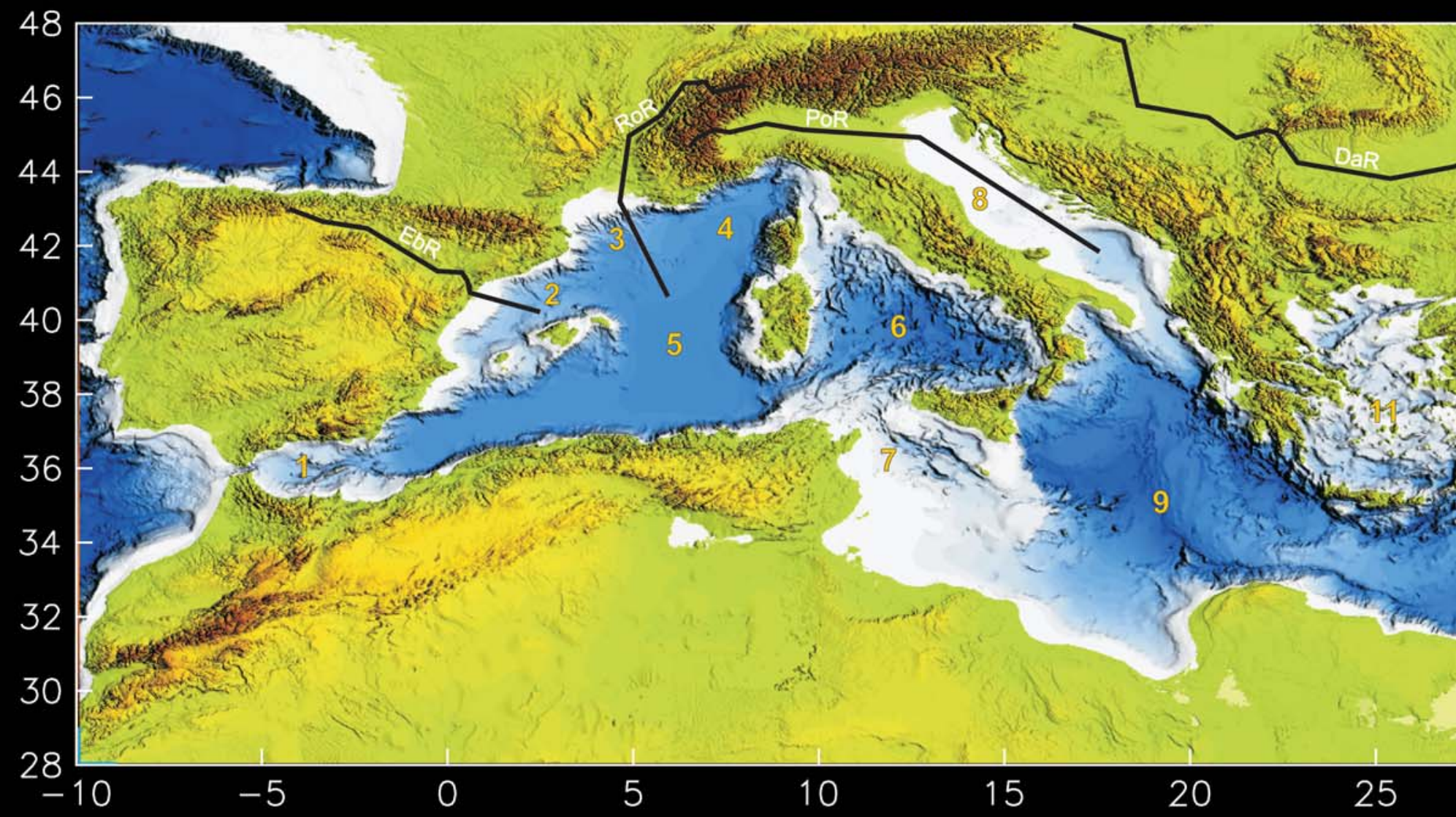

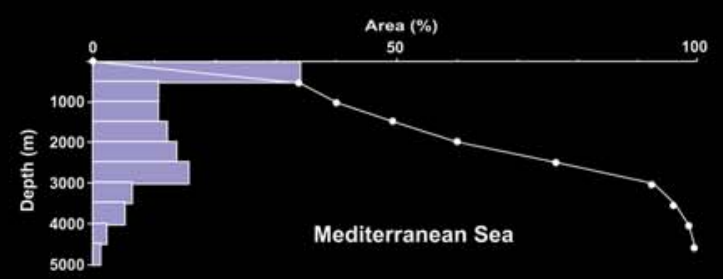

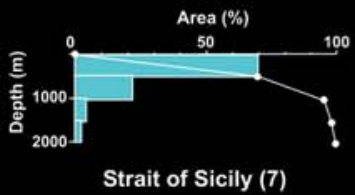

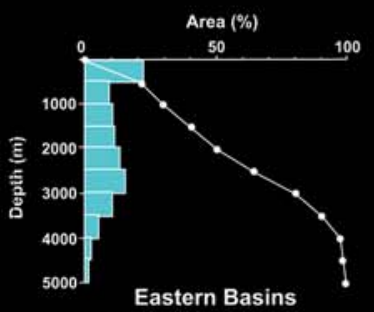

(Ionian Sea (9), Levantine Basin (10)) 


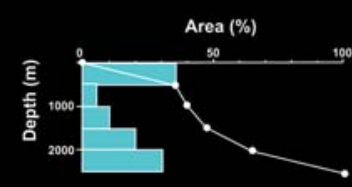

Black Sea (13)

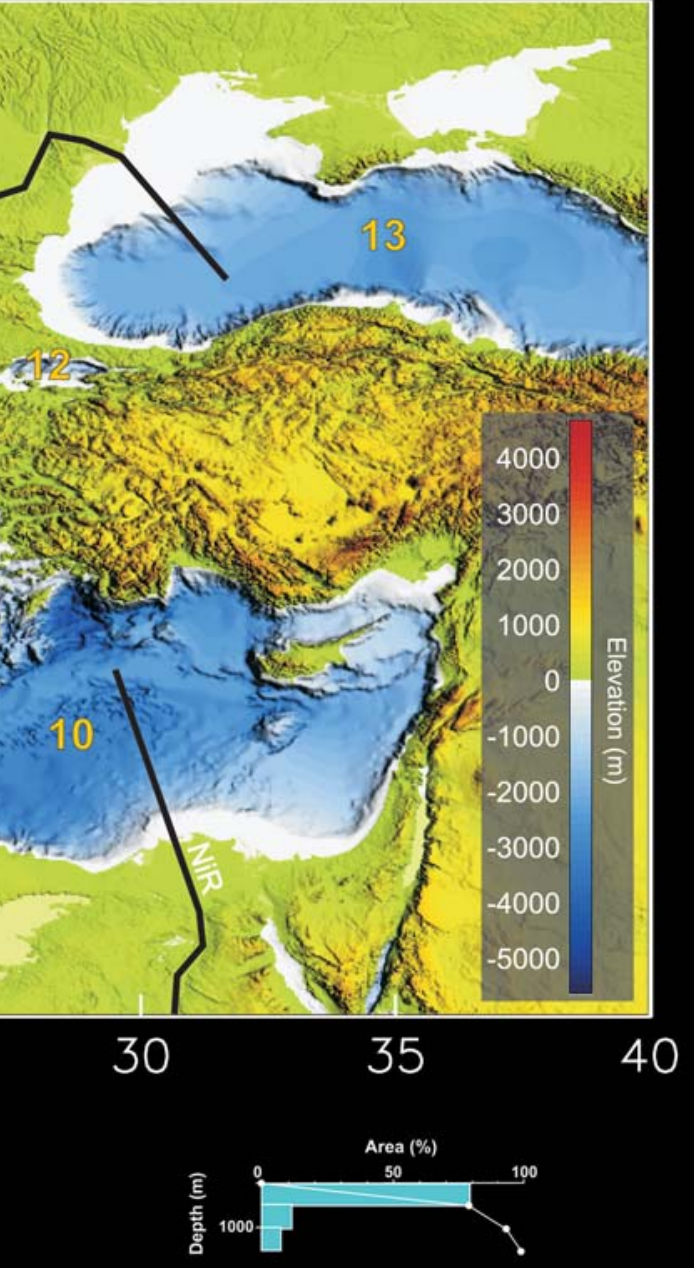

Marmara Sea (12)

\section{STRUCTURAL BACKGROUND OF}

\section{THE MEDITERRANEAN}

After a complex tectonic history of thrusting and rifting involving the Eurasian, African, and Arabian plates, the northward motion of Arabia finally closed the link between the eastern parts of the Mediterranean and the remnants of the Tethys Ocean in the late Miocene, around 9 million years ago. From this time onwards, the Mediterranean developed the enclosed basin physiography that is seen today.

The Mediterranean Sea is a geologically active region as shown by its seismic and volcanic activity, and the uplift of present-day landmasses. The landscape thus continues to develop in a highly dynamic manner, which has important consequences for this region's continental margin. Some of the main geological structures in the Mediterranean are clearly reflected in its present seafloor morphology.

\section{OVERALL PHYSIOGRAPHY OF}

\section{THE MEDITERRANEAN}

The Mediterranean Basin occupies an area of almost 2.6 million $\mathrm{km}^{2}$, with an average water depth of approximately $1,500 \mathrm{~m}$. The Mediterranean Sea is composed of a series of small basins (Figure 1) involving a large number of continental fragments. These basins, which

David Amblàs is Ph.D. Student, GRC Geociències Marines, Universitat de Barcelona, Spain. Miquel Canals (miquelcanals@ub. edu) is Professor, GRC Geociències Marines, Universitat de Barcelona, Spain. Galderic Lastras is Associate Professor, GRC Geociències Marines, Universitat de Barcelona, Spain. Serge Berné is Senior Research Scientist, Institut français de recherche pour l'exploitation de la mer (IFREMER), Plouzané Cedex, France. Benoît Loubrieu is Research Assistant, Institut français de recherche pour l'exploitation de la mer (IFREMER), Plouzané Cedex, France.

Figure 1. Topography and bathymetry of the Mediterranean region at one minute (latitude by longitude) grid resolution produced from the GEBCO Digital Atlas published by the British Oceanographic Data Centre on behalf of the International Ocean Commission, International Hydrographic Organization, and British Oceanographic Data Centre (2003). The Mediterranean Sea is composed of several individual basins. The hypsographic curves for these basins tell us about the morphogenetic processes that have shaped them. Color bars represent the distribution of the areas at $500 \mathrm{~m}$ depth intervals, and white dots illustrate the depth cumulative curves. As we observe in the hypsographic curves, we can group the Mediterranean basins into: (a) Shelf basins, with depths usually less than 500 m (Adriatic Sea, Aegean Sea, Marmara Sea, Strait of Sicily); (b) Margin-dominated basins, with a balanced areal distribution of continental shelf, slope, rise, and abyssal plain sections (western Mediterranean basins in general, and the Black Sea); (c) Deep basins, predominated by abyssal plains (Tyrrhenian Sea, Ionian Sea, and Levantine Basin). The physiographic distribution of each basin mainly results from the interplay between tectonic and sedimentary evolution processes. The whole Mediterranean hypsographic curve shows an overall balanced distribution of the main submarine physiographic provinces. Bold black lines show the location of the topographic profiles (Figure 2) along the main river systems, from their catchment areas to the deeper parts of the associated submarine continental margins. EbR: Ebro River; RoR: Rhône River; PoR: Po River: DaR: Danube River; NiR: Nile River. 
are very different in terms of dimensions, physiography, and geologic evolution, can be grouped into western and eastern sets, separated by the relatively shallow Strait of Sicily. The Black Sea is an isolated basin adjacent to the eastern Mediterranean Sea.

The western Mediterranean has an area of approximately 0.9 million $\mathrm{km}^{2}$, and it includes the Alboran Sea, the Algerian-Balearic Basin, the Catalano-Balearic Sea, the Gulf of Lions, the Ligurian Sea, and the Tyrrhenian Basin. At the westernmost end of the western Mediterranean area there is the only connection of the present Mediterranean Sea to the global ocean through the Gibraltar Strait. This passage, only $14 \mathrm{~km}$ wide, exerts an important control on the water circulation in the Mediterranean Sea and has largely determined its singularity.

The continental shelves tend to be narrow off the southern and northern Iberian Peninsula, the Balearic Islands, Corsica, Sardinia, the western Italian coast, northern Africa, and the Mari- time Alps, where mountain slopes drop almost straight into the sea. Larger continental shelves, more than $50 \mathrm{~km}$ wide, are present off the Ebro and Rhône Rivers mainly due to the progradation of deltaic systems (Figure 2). The continental shelf off the north of Tunisia is also wide, but in this case, it is because of structural control. Bathyal plains occupy large areas in the western Mediterranean. These are located between the Balearic Islands, north of Africa and Sardinia with depths reaching $2,800 \mathrm{~m}$, and

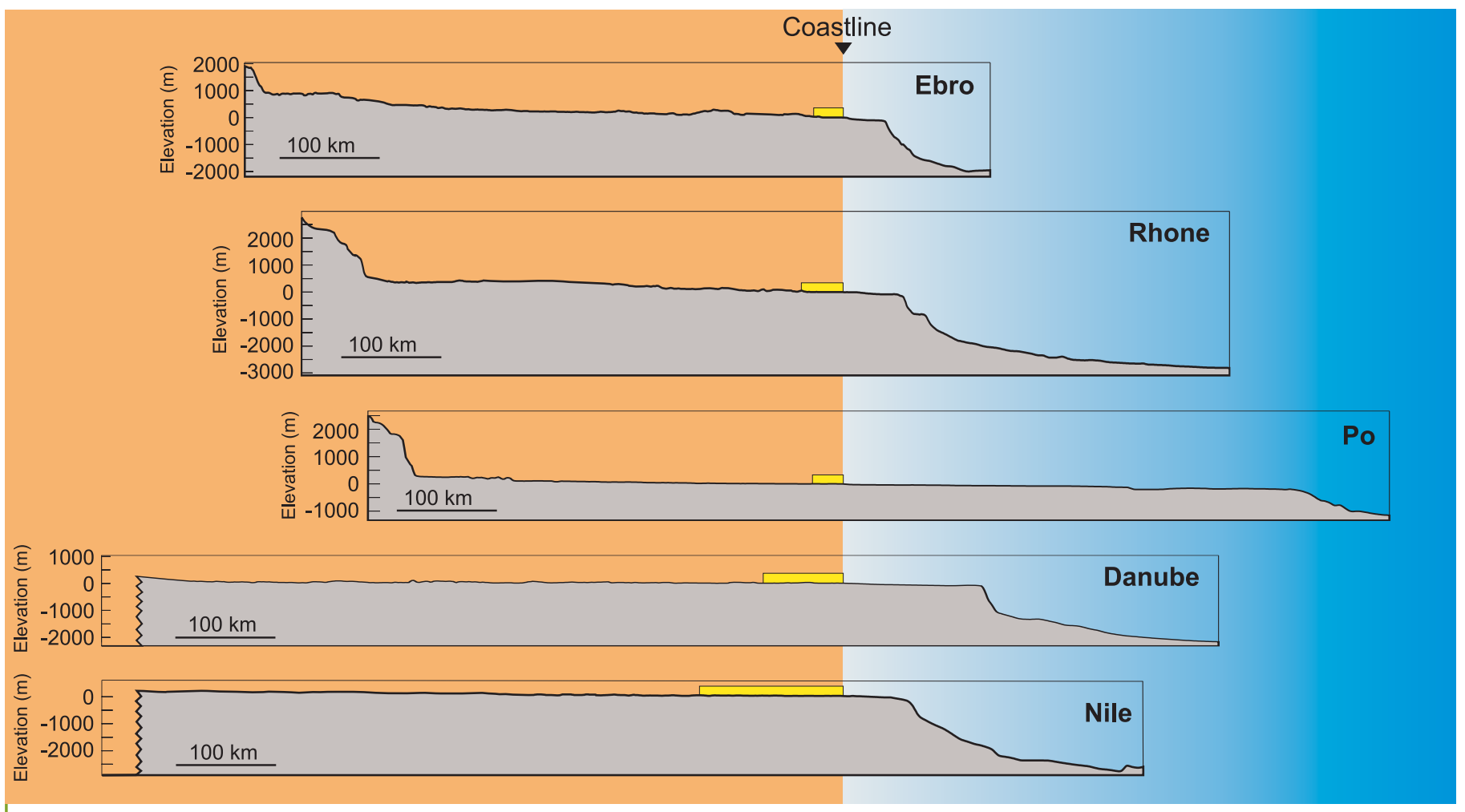

Figure 2. Topographic profiles along the main river systems of the Mediterranean, from catchment areas to the deeper parts of the associated continental margins. See Figure 1 for location. The profiles have been drawn in a way that they extend onshore and offshore from coastline for ease of comparison. Yellow rectangles show the extent of the present-day emerged deltaic plains. Because of the length of the Nile and Danube Rivers, which are over 6,650 km and 2,850 km, respectively, their upper courses and headwaters are not represented. The Ebro, Rhône, Po, Danube, and Nile Rivers are characterized by large hydrographic basins and by large associated deltas that have prograded for tens to hundreds of kilometers. The submarine shape of these fluvial-influenced margins is highly variable. The enclosed, shallow character of the Adriatic Basin largely determines the large-scale geometry of deposits contributed by the Po River. The Ebro, Rhône, Danube, and Nile Rivers, which develop without major physiographic constraints, have developed prograding continental shelves and slopes leading to wide continental rises. Note the differences between the sizes of the emerged deltaic plains. 
in the Tyrrhenian basin with depths up to $3,430 \mathrm{~m}$. These bathyal plains formed during the thinning of continental crust that took place in the rifting phases when the Balearic Islands, Corsica, and Sardinia rotated away from the Eurasian continent, and the Tyrrhenian Sea opened.

Conversely, the eastern Mediterranean has a highly varied physiographic character. It includes the Strait of Sicily, the Adriatic Sea, the Ionian Sea, the Levantine Basin, the Aegean Sea, and the Marmara Sea. The eastern Mediterranean occupies an area of approximately 1.7 million $\mathrm{km}^{2}$. These seas and basins are underlain by oceanic crust under their main area, and thinned continental crust below their peripheries. This sector is more difficult to describe in terms of physiography than the western basins. There are important tectonic structures that determine the morphology and development of the basins. The main structures clearly visible in the bathymetry of the eastern Mediterranean are the Hellenic Trench and the Mediterranean Ridge. The Hellenic Trench is a subduction zone reaching a maximum depth of 4,661 m to the west of Crete and represents the deepest point in the Mediterranean. This trench confines the Aegean Sea to the north, arching from the western Peleponnese to southeast of Rhodes Island, which lies southwest of the Anatolian Peninsula. The Mediterranean Ridge runs parallel to this structure, from the Ionian Basin to the west, to the Cyprus arch to the east. This 1,500-km-long structure represents a huge wedge-shaped tectono-sedimentary body emplaced as a consequence of the Africa-Aegean plates convergence.

The continental shelves in the eastern

\section{Because of its geographic and geologic variability, the Mediterranean may be \\ used as an almost perfect laboratory for studying landscaping processes on submarine environments.}

basin are narrow off Peleponnese, Crete, and southern and northern Turkey. However, they are well developed particularly to the east of Tunisia, in the area directly under the influence of deposits from the Nile River delta, and in the Adriatic, where large portions are shallower than $100 \mathrm{~m}$ (Figure 2). The Aegean Sea is also relatively shallow, a result of its relatively young crust rather than high sediment input. Basin floors are deeper, but smaller, than those in the western basin. Maximum depths are up to 4,200 $\mathrm{m}$ in the Ionian Abyssal Plain and 3,200 $m$ in the Herodotus Abyssal Plain.

The Black Sea is an inland sea segregated from the eastern Mediterranean, connecting only to the Bosphorus Strait and the Marmara Sea. Its floor, with depths up to 2,130 $\mathrm{m}$, is shallower than those observed in the Mediterranean. The continental shelves are narrow on the Black Sea's southern margin, and due to the Danube River's influence, are wide on its northern margin (Figure 1).

\section{THE FLUVIAL-DOMINATED SEASCAPES OF THE \\ MEDITERRANEAN}

Continental margins are affected by processes extending from sediment source to sediment sink or, in other words, from erosional to depositional areas. From this viewpoint the margin may be divided into different units that are interlinked by the flux of sediment: emerged lands, continental shelf, continental slope, continental rise, and basin floor.

Taking a general overview of the Mediterranean region topography we note that, apart from the deltaic zones of large rivers, the coastlines are mostly surrounded by mountain ranges (Figure 1). Only the coastal plains from eastern Tunisia to the Sinai Peninsula are free of mountains. The existence of surrounding mountains largely determines the seascape of the Mediterranean since it makes the basin boundaries very steep, thus impeding the development of settlements. In addition, the potential energy storage from mountainous areas makes the amount of erodible sediments very high. These sediments are then transported downslope by both permanent and non-permanent rivers, therefore contributing to the infill of this landlocked basin.

Locally modern-day sedimentation is dominated by organic-rich oozes, volcanic ashes, or aeolian sediments mostly coming from the arid areas of northern Africa. However, the seascape of the Mediterranean Sea is primarily related to its fluvial regime, aside of those areas dominated by neo-tectonics or volcanic processes.

There are few large rivers with well- 
defined coastal plains and deltas in the

Mediterranean Sea. The most important ones from west to east are: Ebro, Rhône, Po, Danube, and Nile (Figure 2). These are perennial rivers supplied by very large hydrographical basins that in most cases collect water beyond the boundaries of the Mediterranean climatic belt. Smaller rivers play an important role in margin sedimentation but are either ephemeral or carry small volumes of water due to the seasonal and sporadic nature of rainfall in most Mediterranean environments. Despite the rainfall regime being highly variable both at the basin scale and regional scale, the precipitation is usually low, often below 500 $\mathrm{mm}$ of total annual rainfall. These low precipitation rates, combined with high evaporation and infiltration, explain why most riverbeds are dry most of the year. This makes the closure of the mouths of many Mediterranean rivers by sediment bars a common feature.

The Ebro, Rhône, Po, Danube, and Nile deltas formed after the wedgeshaped accumulation of terrigenous materials at varying sedimentation rates main growth stage defining the deltas we know today started with the attainment of the modern sea-level highstand, from about 8,500 to 6,500 years ago. One of the most studied delta systems in the Mediterranean is the Ebro delta (Figure 3), covering an area of $2,170 \mathrm{~km}^{2}$, of which only $320 \mathrm{~km}^{2}$ correspond to its subaerial part. The modern delta consists of transgressive and highstand deposits accumulated during the Holocene, from 10,000 years before present to the present (Somoza et al., 1998). Its shape is inherited both from river influence and marine dynamics. The construction of large dams and the increase in water management along the Ebro system during the last century resulted in the dramatic reduction of sediment discharge at the river mouth. Therefore, the impact of human activities on the shape and development of the Ebro Delta is not only noticeable but will grow in the coming decades (see Liquete et al., this issue).

The Messinian salinity crisis event refers to the drying up of the Mediterranean that produced a dramatic change in the sedimentation and a marked land-

\section{Currently, multibeam echosounders are acquiring}

unprecedented highly detailed seafloor images.

\section{As a consequence, our knowledge of seafloor sculpting processes is improving rapidly.}

(up to $10 \mathrm{~cm} / \mathrm{yr}$ ). These depositional systems have prograded for hundreds of kilometers since the end of the Messinian salinity crisis, about 5 million years ago (see below). Despite this, the scape change in the region (Clauzon et al., 1996). In fact, apart from those areas morphologically controlled mainly by deltaic systems or neo-tectonic processes, the present seascape has been strongly determined by the Messinian event. The dramatic sea-level fall (due to the complete closure of the seaways between the Atlantic and the Mediterranean at that time) caused a spectacular change in the rivers' base levels and a major erosional discontinuity in the margin. During this time, a series of evaporites, over 1,500 $m$ thick in some places, were deposited in the Mediterranean basin floors. Salt tectonics related to these deposits are still playing a key role in margin morphodynamics over large areas. Currently, the landscaping impact of the Messinian event can be observed onshore as deeply incised palaeovalleys filled with later sediments. Offshore, it is also thought that the morphology of some deep submarine canyons is inherited from Messinian times.

One of the best examples of continental slope and shelf canyon incision is the Gulf of Lions located in the northwestern Mediterranean (Figure 4). As in other areas of the Mediterranean, some of its canyon systems relate directly to Messinian incisions. Others are linked to the position of former streams during PlioQuaternary lowstands (i.e., the Last Glacial Maximum lowstand) (Berné et al., 1999). Other canyons originated through retrogressive slides, independent of former features in the shelf (Alonso et al., 1991; Pratson, 1996; Berné et al., 1999) and some are related to faults or salt-tectonics. The shape and dimension of canyons differ substantially from each other. There are canyons deeply incised into the continental shelf, others restricted to the slope, others sinuously shaped, and some with roughly linear morphologies. Mediterranean canyons can be hundreds of kilometers long, several kilometers 


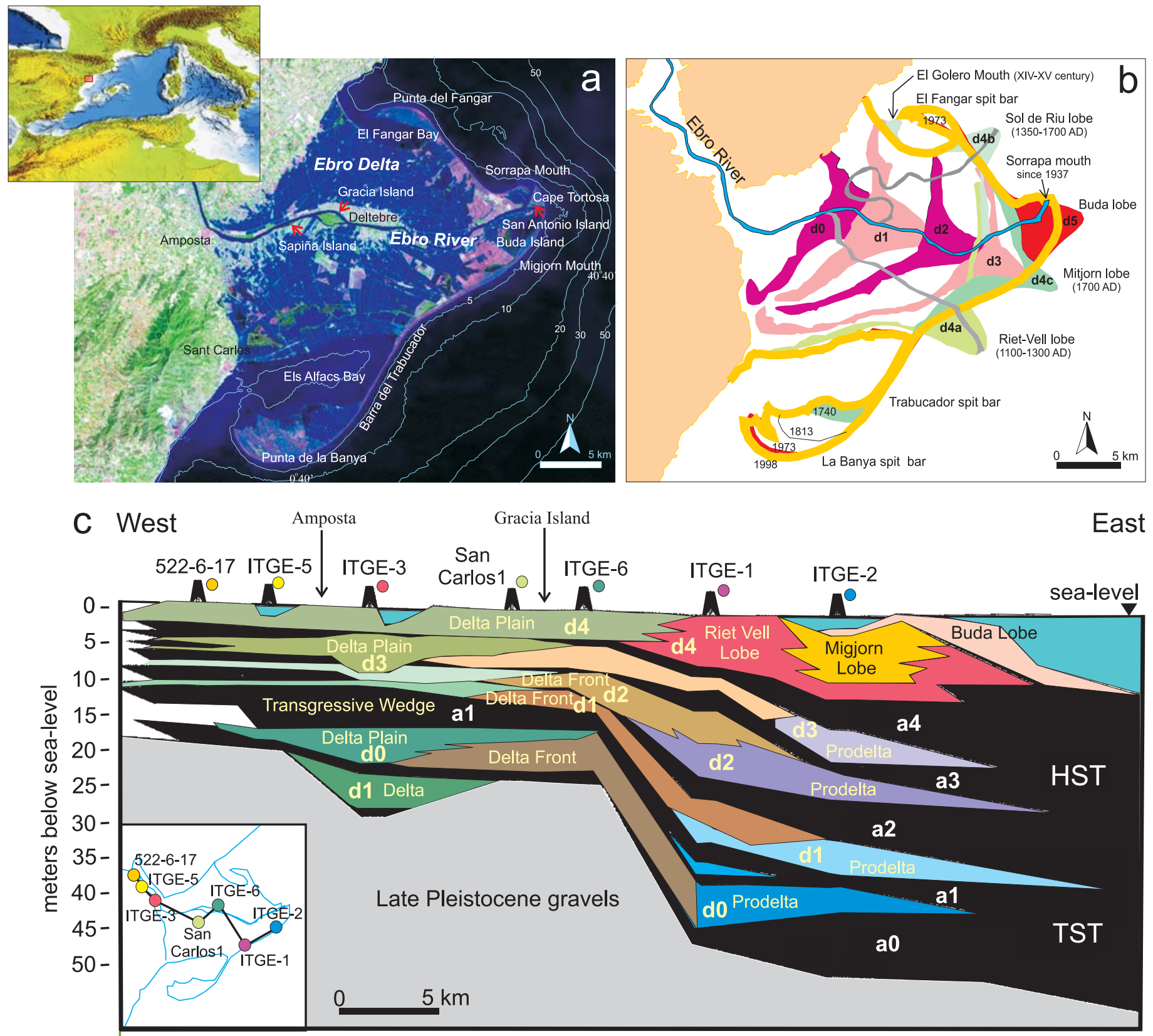

Figure 3. (a) Landsat image of the Ebro delta. The overall shape of the Ebro delta corresponds to a river-dominated delta reshaped by marine dynamics. (b) Map showing a reconstruction of the Holocene evolution of the Ebro delta lobes based on correlation between well logs, highresolution seismic profiles, electric subsurface conductivity maps, and historical data (modified from Somoza et al., 1998). The Ebro prodelta is made of several lobate sedimentary wedges surrounding the subaerial delta, which result from the migration and stacking of former deltaic lobes. (c) Well-log correlation of Holocene sedimentary units beneath the Ebro delta plain. Deposits in black are aggradational (marine clay wedges, inland peats), whereas those with colors are progradational deltaic deposits. The latter units consist of sandy delta-front facies with clinoforms grading seawards into prodeltaic grey silts, and landwards into delta plain red silts and pebbly sands (modified from Somoza et al., 1998). The modern Ebro delta consists, therefore, of transgressive and highstand deposits accumulated during the Holocene (10,000 years ago to present). The overall stacking pattern of this Mediterranean delta is progradational. 


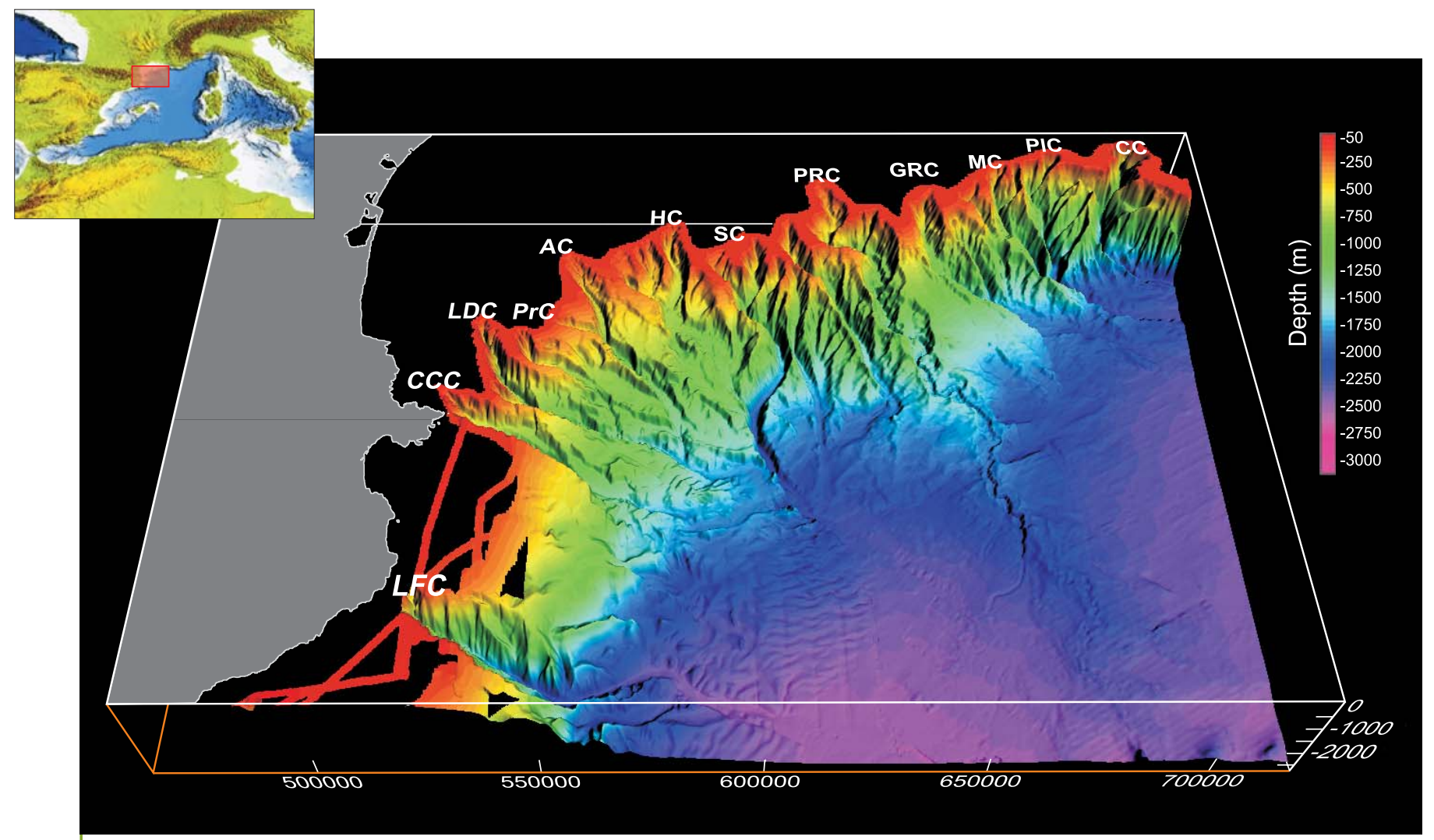

Figure 4. Three-dimensional view of the Gulf of Lions and Northern Catalan margin. This swath map is generated by multibeam data acquired during several cruises by Ifremer and the University of Barcelona. Vertical scale is magnified 12 times. The continental margin is characterized by the presence of canyons deeply incised into the continental shelf and slope. These erosive features reach, in some cases, hundreds of kilometers long, several kilometers wide, up to $800 \mathrm{~m}$ incised into the slope with slope gradients of over 20 degrees on the walls. Note the presence of a huge continental rise deposit related upslope to the Petit-Rhône Canyon system. This feature corresponds to the Rhône Deep Sea Fan (shown in Figure 5). LFC: La Fonera Canyon; CCC: Cap de Creus Canyon; LDC: Lacaze-Duthiers Canyon; PrC: Pruvost Canyon; AC: Aude Canyon; HC: Hérault Canyon; SC: Sète Canyon; PRC: PetitRhône Canyon; GRC: Grand-Rhône Canyon; MC: Marseille Canyon; PIC: Planier Canyon; CC: Cassidaigne Canyon.

wide, up to $800 \mathrm{~m}$ incised into the slope and with gradients of over 20 degrees on their walls (see Canals et al., this issue).

Canyons generally evolve downslope to well-developed channel-levee complexes at the base of the continental rise. These sedimentary systems typically supply deep sea fans, which often represent the terminal storage of sediment coming from the surrounding emerged lands. The Nile deep-sea fan, covering about $140,000 \mathrm{~km}^{2}$, is one of the largest submarine fan-shaped terrigenous deposits in the world. Sediments in there are trans- ported by the Nile River drainage system and originate from large eroded areas in the African craton. On the Gulf of Lions' continental rise in the western Mediterranean, large depocenters are also observed. Of these, the Rhône Fan is the largest, with a maximum width of over $90 \mathrm{~km}$ (Figure 5) (Droz and Bellaiche, 1985).

Slope instability is also a major process mobilizing sediment from the continental slope, even from the shelf edge or further downslope, to the deeper parts of the continental margin. These mass-wasting events can transport huge amounts of sediment and reshape the seafloor very quickly when compared to other previously mentioned processes. In the Mediterranean Sea, numerous mass-movement deposits have been identified. Among these, the BIG'95 submarine landslide is prominent (Figure 6), with a $26 \mathrm{~km}^{3}$ deposit covering 2000 $\mathrm{km}^{2}$ of the Ebro continental slope and base of slope (Lastras et al., 2002). The occurrence of this event has been dated using sediment cores, giving an age of about 11,500 years before present. Other mass-movement deposits have been 


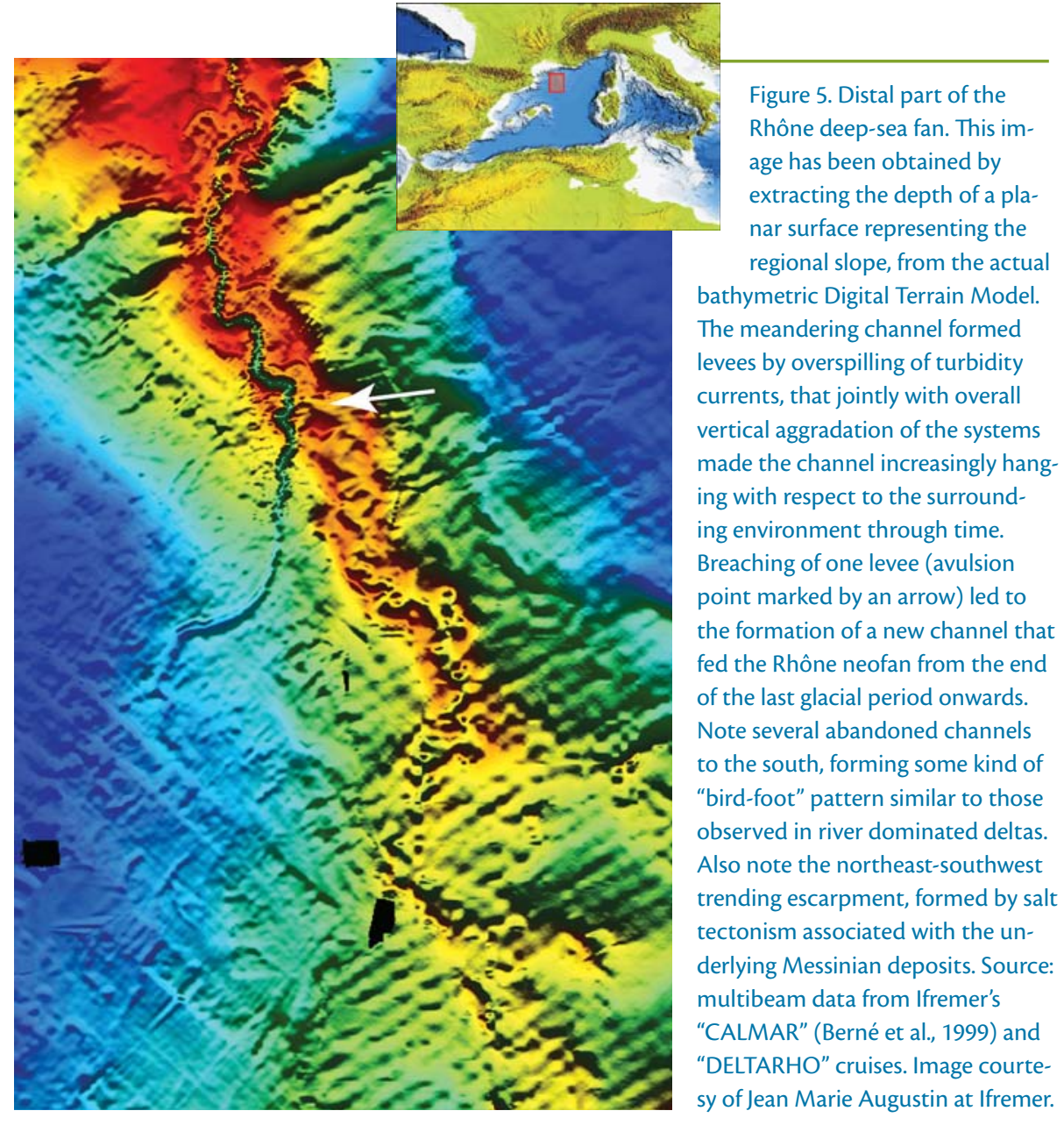

identified in the western Mediterranean, mainly on the Gulf of Lions continental rise, where several other quite recent (around 21,000 years before present) debris-flow deposits have been described (Droz et al., 2001).

In some cases, submarine canyonchannel systems join together at the base of the continental slope or in the continental rise and continue as a single, and often margin-parallel, deep-sea channel. The Valencia Channel, located on the Catalano-Balearic Sea, is a well-developed example in the western Mediterranean (Figure 7). This deep-sea chan- nel trends northeastwards following the Valencia Trough axis, an early Miocene-Pleistocene extensional basin that separates the Iberian margin to the west from the Balearic margin to the east. The Valencia Channel not only collects sediment transported from the canyonchannel systems eroded into the Catalan margin, but also from the Ebro turbiditic system (Canals et al., 2000) and by large unconfined mass-wasting events. Among the latter, the BIG'95 submarine landslide, which partially buries the uppermost course of the Valencia Channel, is the most outstanding example. This deep-sea channel finally vanishes into the Valencia fan, at the northernmost part of the Algerian-Balearic abyssal plain, $400 \mathrm{~km}$ away from its head.

Apart from trenches, the deepest physiographic unit in sea basins is the abyssal plain. In the Mediterranean these are shallower (up to $4,200 \mathrm{~m}$ in depth) than those in the larger ocean basins (from 3,000 $\mathrm{m}$ to $6,000 \mathrm{~m}$ in depth). The sediments in this environment are mainly composed of very fine particles from hemipelagic settling because most of the coarser sediment coming from the emerged lands is left on the continental shelf, slope, and rise. Exceptions occur when large, powerful turbidity currents carry coarse sediment across the abyssal plain from further upslope. In fact, the largest mass-wasting deposit observed in the western Mediterranean Sea is the $60,000 \mathrm{~km}^{2}, 500 \mathrm{~km}^{3}$ turbiditic deposit that occupies almost the whole Algerian-Balearic abyssal plain (Rothwell et al., 1998). Despite its importance in terms of area and volume, it lacks a prominent signature on the western Mediterranean seascape.

\section{CONCLUDING REMARKS}

The submarine morphology of ocean basins and margins discussed here illustrate the processes that have generated it. The analysis of the seascape, combined with sub-seafloor studies, is necessary to understand the mechanisms of continental margin evolution. Currently, multibeam echosounders are acquiring unprecedented highly detailed seafloor images. As a consequence, our knowledge of seafloor sculpting processes is improving rapidly.

The present seascape of Mediterranean basins is mainly controlled by neo- 


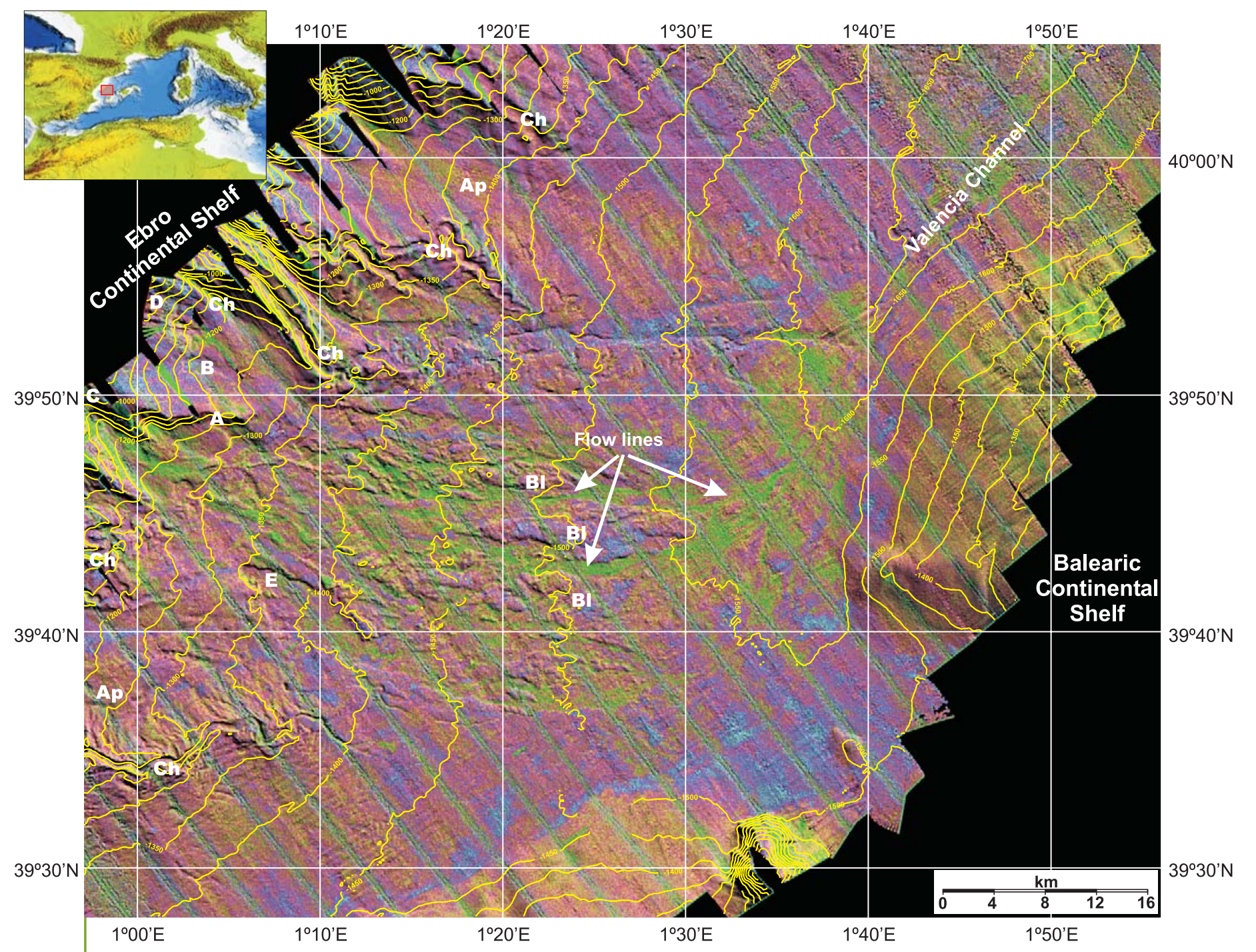

Figure 6. Seafloor-backscatter data are used to image the product of one of the youngest major mass-wasting events in the Northwest Mediterranean Sea: a $26 \mathrm{~km}^{3}$ debris-flow deposit that covers 2,000 km² of the Ebro continental slope and base-of-slope offshore eastern Iberian Peninsula. This combined backscatter (green: highest backscatter; purple and blue: lowest backscatter) and shaded relief map of the BIG'95 debris flow area (contours every $50 \mathrm{~m}$ ) shows a pattern of low-backscatter patches representing large sediment blocks that moved while keeping their internal coherence, and high-backscatter alignments restricted to topographic lows that represent coarse sediment pathways amongst the blocks. A: headwall; B to E: secondary scars; Bl: debris blocks; Ap: apron; Ch: canyon-channel system. Flow lines are also labelled. Northwest-trending striping is an acquisition artifact. Modified from Lastras et al. (2002).

tectonic processes and fluvio-sedimentary systems. Among the latter, the deposits and sediment bypass structures related to the activity and inputs of the largest rivers stand out. Because of its geographic and geologic variability, the Mediterranean may be used as an almost perfect laboratory for studying landscaping processes on submarine environments.

\section{ACKNOWLEDGEMENTS}

We thank the support of the European projects COSTA (EVK3-1999-00028), EUROSTRATAFORM (EVK3-CT-2002-
00079), EURODELTA (EVK3-CT-20021020001), and EURODOM (HPRN-CT2002-00212), the Spanish RTD project PRODELTA (REN2002-02323), the Generalitat de Catalunya GRC grant (2001SGR-00076), and a Spanish MECD FPU fellowship (Amblàs). @ 


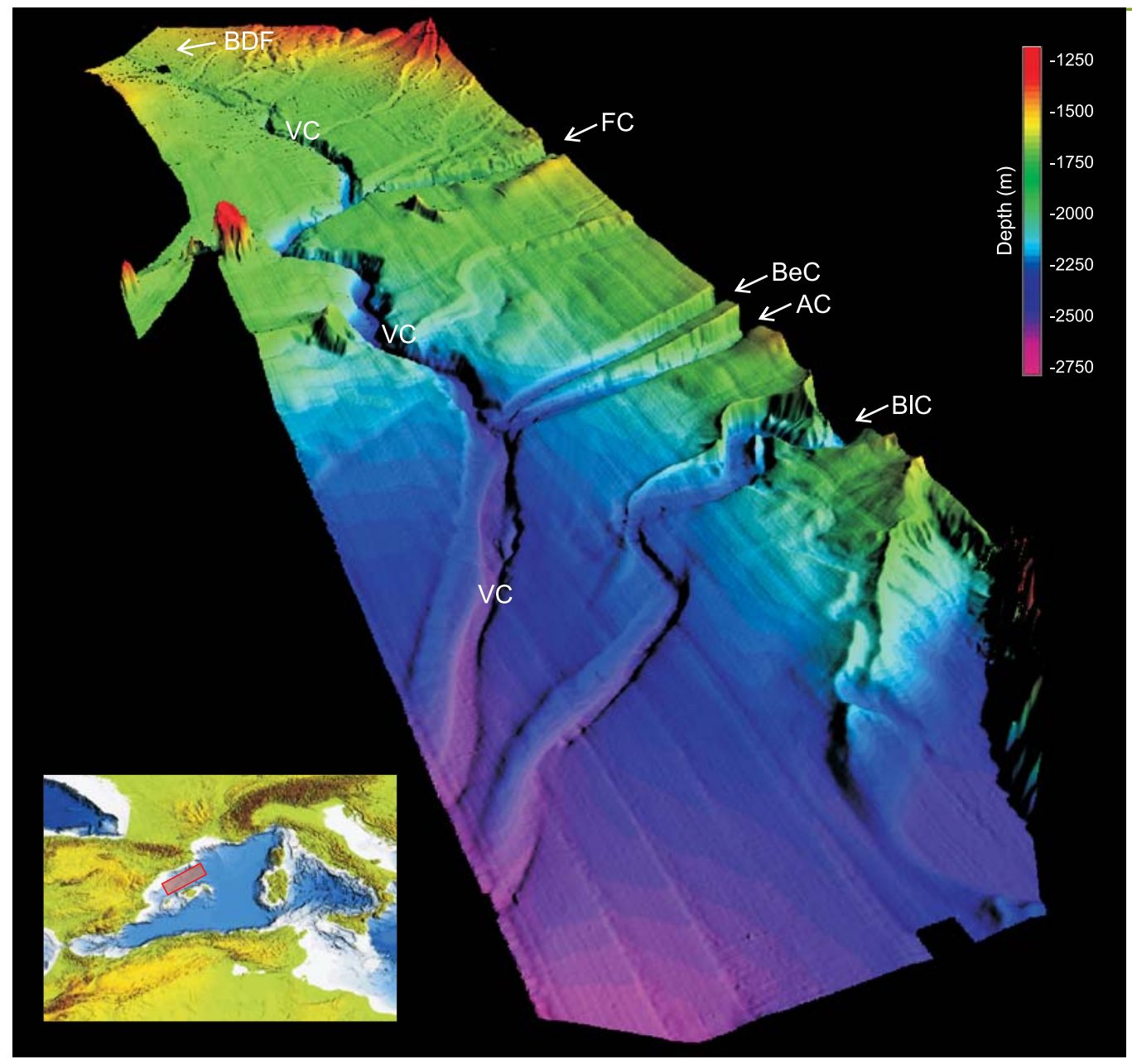

Figure 7. Three-dimensional view of the Valencia Channel. This shaded relief image is generated by multibeam data acquired during University of Barcelona's "Marinada" and "BIG-95" cruises. Vertical scale is magnified 12 times. The Valencia Channel is a deepsea channel more than $400 \mathrm{~km}$ long that ranges from $2,000 \mathrm{~m}$ to $2,500 \mathrm{~m}$ in depth. It runs parallel to the northeastern Iberian margin, collecting sediment from the Ebro turbidite system channels, from the canyon systems eroded into the Catalan margin, and from large unconfined mass-wasting events (i.e., the BIG'95 debris flow). Note the connection of these tributary systems with the Valencia Channel. This drainage system leads into the Valencia fan, at the northernmost part of the Algerian-Balearic abyssal plain. On a global scale, deep-sea channels are less common than other types of sea valleys, such as canyons, turbiditic channels, or slope gullies. VC: Valencia Channel; FC: Foix Canyon; BeC: Besós Canyon; AC: Arenys Canyon; BIC: Blanes Canyon; BDF: BIG'95 Debris Flow.

\section{REFERENCES}

Alonso, B., M. Canals, H. Got, and A. Maldonado. 1991. Seavalleys and related depositional systems in the Catalan Sea (Northwestern Mediterranean Sea). AAPG Bulletin 75(7):1195-1214.

Berné, S., B. Loubrieu, and the CALMAR shipboard party. 1999. Canyons et Processus Sédimentaires Récents sur la Marge Occidentale du Golfe du Lion. Premiers Résultats de la Campagne Calmar. Comptes Rendus Académie des Sciences Paris 328:471-477.

Canals, M., J.L. Casamor, R. Urgeles, G. Lastras, A.M. Calafat, M. De Batist, D. Masson, S. Berné, B. Alonso, and J.E. Hughes-Clarke. 2000. The Ebro continental margin, Western Mediterranean Sea: Interplay between canyon-channel systems and mass wasting processes. Pp. 152-174 in Deep-water Reservoirs of the World, C.H. Nelson, and .P. Weimer, eds. GCSSEPM Foundation 20th Annual Research Conference, Houston, Texas, USA (CD edition).
Clauzon, G., J.P. Suc, F. Gautier, A. Berger, and M.F. Loutre. 1996: Alternate interpretation of the Messinian Salinity Crisis: Controversy resolved? Geology 24:363-366

Droz, L., and G. Bellaiche.1985. Rhône Deep-sea Fan: Morphostructure and Growth pattern. AAPG Bulletin 69(1):460-479.

Droz, L., R. Kergoat, P. Cochonat, and S. Berné, 2001. Recent Sedimentary Events in the Western Gulf of Lions (Western Mediterranean). Marine Geology 176:23-37.

International Ocean Commission, International Hydrographic Organization, and British Oceanographic Data Centre (IOC/IHO/ BODC). 2003. Centenary Edition of the GEBCO Digital Atlas, published on CD-ROM on behalf of the Intergovernmental Oceanographic Commission and the International Hydrographic Organization as part of the General Bathymetric Chart of the Oceans. British
Oceanographic Data Centre, Liverpool.

Lastras, G., M. Canals, J.E. Hughes-Clarke, A.

Moreno, M. De Batist, D.G. Masson, and P. Cochonat. 2002. Seafloor imagery from the BIG'95 debris flow, western Mediterranean. Geology 30(10):871-874.

Pratson, L.F., and B.J. Coakley. 1996. A Model for the headward erosion of submarine canyons induced by downslope-eroding sediment flows. GSA Bulletin 108(2):225-234.

Rothwell, R.G., J. Thomson, and G. Kähler. 1998. Low sea-level emplacement of a very Large Late Pleistocene "megaturbidite" in the western Mediterranean Sea. Nature 392:377-380

Somoza, L., A. Barnolas, A. Arasa, A. Maestro, J.G. Rees, and F.J. Hernandez-Molina. 1998. Arquitectural stacking patterns of the Ebro Delta controlled by Holocene high-frequency eustatic fluctuations, delta-lobe switching and subsidence processes. Sedimentary Geology 117:11-32. 